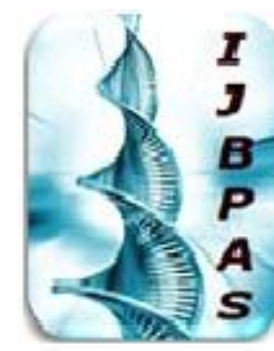

International Journal of Biology, Pharmacy and Allied Sciences (IJBPAS)

'A Bridge Betuen Caboratory and Q Qndor'

WWw.ijbpas.com

\title{
ISOLATION, IDENTIFICATION AND ANTIBIOTIC SUSCEPTIBILITY OF \\ PROBIOTIC LACTOBACILLUS PLANTARUM NRC AM10
}

\section{MABROUK AMM*, EFFAT BAM AND SADEK ZIM}

Dairy Science Department, Microbiology Laboratory, National Research Centre, Dokki,

$$
\text { Cairo, 12311, Egypt }
$$

*Corresponding Author - E-mail: mabrouk455@hotmail.com

Received 10 ${ }^{\text {th }}$ Oct. 2018; Revised $9^{\text {th }}$ Nov. 2018; Accepted $20^{\text {th }}$ Nov. 2018; Available online $1^{\text {st }}$ March 2019

\section{https://doi.org/10.31032/IJBPAS/2019/8.3.4661}

\begin{abstract}
The Lactobacillus is a very important genus of lactic acid bacteria commonly found in nature in different fermented foods. Different species of this genus were used worldwide in food fermentations as probiotics. Therefore, the purpose of the present study was to isolate, identify probiotic Lactobacillus strain from fermented goat milk and determine the antibiotic susceptibility and carbohydrate fermentation patterns. According to the phenotypic characterization and carbohydrate fermentation profile (API ${ }^{\circledR} 50$ CHL strip), the tested strain will identified as Lactobacillus plantarum NRC AM10 with $99.9 \%$. The strain confirmed by both PCR and sequencing as the same strain with accession number CP023728.1. In addition, our results indicated that the isolated strain showed sensitivity toward nine different types of antibiotic discs (Penicillin G, Erythromycin, Ampicillin10 and $25 \mu \mathrm{g}$, Cephalocin10 and 30 $\mu \mathrm{g}$, Clindamycin, Cortimoxazole and Nitrofurantion). On the other hand, the tested strain showed good resistance to the other types of antibiotic discs. The strain showed a good acidity development in skim milk and able to coagulate the milk after $16 \mathrm{~h}$ of incubation time. In conclusion, the natural fermented dairy products are good valuable sources for isolation of lactic acid bacteria with good probiotic and technological characteristics.
\end{abstract}

Keywords: Lactic acid bacteria, Lactobacillus plantarum, probiotic dairy products, antibiotic discs, technological characteristics 


\section{INTRODUCTION}

Nowadays, the consumption of dairy products supplemented with probiotics are receiving great deal of attention all over the world. These probiotics able to support and improvement the human health, enhance the microbial balance in the gut and use in fermented probiotic food productions [1, 2, 3, 4]. Lactic acid bacteria (LAB) have an essential role for extending the shelf life of fermented foods, like yoghurt, cheese, pickled olives, sauerkraut, meat products, vegetables, fish products and sourdough[5, 6]. Lactobacillus plantarum strains can use as biocontrol agents against potentially harmful microorganisms during food processing, storage and increase the shelf life, and safety of fermented foods [7]. Probiotics are live microorganisms which when administered in adequate amounts confer a health benefits on the host [8]. Different researches were done to isolate special probiotic lactic acid cultures for enhancing the quality and organoleptic properties of dairy products [9].Traditional fermented dairy products are good valuable sources of LAB genetic biodiversity [10]. Recently, the use of genotypic characterization represented an advance in the taxonomy and identification of LAB. Several researches based only on the biochemical and phenotypic characterization to identify LAB could not differentiate accurately between bacterial species. Thus, the use of molecular biology methods is very important and more accurate for identification of LAB [11, 12]. The Lactobacillus genus is a widespread lactic acid bacterium commonly found in a wide variety of fermented foods. About 183 species of Lactobacillus genus identified and used safely in fermented foods and dairy products $[3,13,14]$. Lactobacillus plantarum named firstly by Orla-Jennsen in 1919 as Streptobacterium plantarum then due to some biochemical and morphological characteristics done by Pederson in1936 he renamed as Lactobacillus plantarum. It is widely used as a starter or adjuvant culture for the production of fermented foods such as milk, vegetables, coffee, meat and silage. In addition, it can found in numerous ecological niches, including the gastrointestinal tract of humans and animals [15, 16, 17]. The medical treatments by different antibiotics especially in children kill pathogens but in the same time, they also disrupt the beneficial microbes in the intestinal tract. This disruption in the microbial balance leads to antibiotic associated diarrhea AAD [18, 19]. Several studies reported that Lactobacillus species were able to antibiotic resistance like $L b$. acidophilus, 
Lb. delbrueckii subsp. bulgaricus [20], Lb. johnsonii [21], Lb. reuteri [22] and $L b$. plantarum [23]. In fact, some probiotic strains with intrinsic antibiotic resistance could be useful for restoring the gut microbiota after antibiotic treatment [24]. Several meta-analyses that report a relative risk reduction of $\mathrm{AAD}$ with the use of probiotics during antibiotic administration [25]. In addition, many studies suggested that probiotics are able to reduce the risk of antibiotic-associated diarrhea $[\mathbf{2 6}, \mathbf{2 7}]$. The minimum effective dose is $10^{7}$ to $10^{10} \mathrm{CFU}$ or $10^{8}$ to $10^{10} \mathrm{CFU}$ daily for efficacy across a wide range of indications [28]. Probiotics are one aspect in a comprehensive strategy to restore gut flora after antibiotic use and return a healthy gut ecosystem. This done by restoring the microbial balance in the gut and increasing the beneficial microbes. Therefore, the main goal of present work planned to study the phenotypic and genotypic characteristics of Lactobacillus strain isolated from goat's milk.

\section{MATERIALS AND METHODS}

\section{Strain isolation and phenotypic}

\section{characterization}

Goat milk sample was homogenized and serially diluted up to $10^{-8}$ using sterile physiological saline $(0.85 \% \mathrm{NaCl} \mathrm{w} / \mathrm{v})$.
One milliliter was plated onto double sterile petri dishes and MRS agar was poured then plates were anaerobically (BBL Gas Pak Anaerobic System, USA) incubated at $37^{\circ} \mathrm{C}$ for $72 \mathrm{~h}$. Pure colonies picked up and examined for gram staining, catalase production $[2,29]$

\section{Carbohydrate fermentation patterns}

The purified strain was tested using $\mathrm{API}^{\circledR} 50 \mathrm{CHL}$ strips incubated at $37^{\circ} \mathrm{C}$ for 24 and 48 hours. These fermentation profiles were compared with the software APILAB plus V5.1 (BioMerieux, Lyon Company, France).

Genomic DNA extraction and polymerase chain reaction (PCR)

The Genomic DNA was extracted from overnight pure culture according to the procedure of MicroSeq $^{\circledR} 500$ DNA bacterial isolation kits protocol. The extracted DNA transferred into new micro centrifuge tube for using in the polymerase chain reaction to amplify the target DNA fragment. Twenty micro liter of extracted DNA was amplified using (veriti ${ }^{\mathrm{TM}}$ thermal cycler, applied biosystems, Singapore, Indonesia) according to the program presents in table (1). The PCR products were stored at $-20{ }^{\circ} \mathrm{C}$ until use in the following step.

Table 1: The program of polymerase chain reaction

\begin{tabular}{|c|c|c|c|c|c|}
\hline \multirow{2}{*}{ Initial step } & \multicolumn{3}{|c|}{ Each of 30 cycles } & \multirow{2}{*}{$\begin{array}{c}\text { Final } \\
\text { extension }\end{array}$} & Final step \\
\hline \multirow{2}{*}{ Hold } & \multicolumn{3}{|c|}{ Cycle } & Hold \\
\cline { 2 - 4 } & Melt & Anneal & Extend & Hold & \\
\hline $95 / 10$ min & $95 / 30 ~ S e c$ & $60 / 30$ Sec & $72 / 45$ Sec & $72 / 10 \mathrm{~min}$ & $4^{\circ} \mathrm{C}$ \\
\hline
\end{tabular}




\section{Purification and sequencing the PCR product}

Polymerase chain reaction product purified and automatically sequenced according to [30]. The obtained genome sequence was analyzed by using applied biosystems $^{\circledR} 3500$ genetic analyzer. The data were compared with the known data in basic alignment search tool (BLAST), NCBI GenBank, www.ncbi.nlm.nih.gov.

\section{Acidifying ability}

The acidifying ability of the tested strain was determined according to the methods described by [31, 32] with some modifications. The tested strain activated in $10 \mathrm{ml} \mathrm{MRS} \mathrm{broth} \mathrm{at} 37^{\circ} \mathrm{C}$ for $18 \mathrm{~h}$ until O.D at $620_{\mathrm{nm}}$ reached to 1.45 using spectrophotometer (UV-VIS spectrophotometer PD-303 UV LTD Japan). After that a conical flask (200 ml) sterile reconstituted skim milk $(12 \% \mathrm{~W} / \mathrm{V})$ was inoculated with $2 \%$ of the previously subculture. The change of $\mathrm{pH}$ was determined using a $\mathrm{pH}$ meter (JENWAY, Instrument Mode 3510) at zero, 4, 6, 12, 16 and $24 \mathrm{~h}$ of incubation at $37^{\circ} \mathrm{C}$.

\section{Antibiotic susceptibility test}

The sensitivity of the tested strain to twenty types of multiantibiotic discs was determined using disc diffusion assay according to [33]. The plates were incubated anaerobically at $37^{\circ} \mathrm{C}$ for $48-72$ h. The sensitivity against antibiotics evaluated by observation the diameter of inhibition zone around the antibiotic discs. The results were expressed as sensitive (S) or resistant $(\mathrm{R})$.

\section{RESULTS AND DISCUSSION}

\section{Phenotypic Characterization}

The isolated strain was identified according to the microscopic examination as gram-positive rods, none sporulation, did not produce $\mathrm{Co}_{2}$ from glucose and catalase negative. On the other hand, according to the carbohydrate fermentation pattern the data sheet illustrate in Figure 1. It was indicated that the isolate able to ferment about 26 type of carbohydrate in $\mathrm{API}^{\circledR} 50$ CHL strip after $48 \mathrm{~h}$ of incubation period and the result sheet was compared with the $\mathrm{API}^{\circledR}$ database, the isolated strain successfully identified as Lactobacillus plantarum with percent $99.9 \%$ table (2).

\section{Genotypic Characterization of The Strain}

The complete nucleotide sequence and electropherogram of Lactobacillus plantarum NRC AM10 were shows in figures (2 and 3). After obtaining, the nucleotide complete sequence of the tested strain it compared with the data deposited in the NCBI Gen-Bank by using the BLAST. After that, the molecular identification showed that the strains was identified as Lactobacillus plantarum with ID number CP023728.1 with high 
similarity with the phenotypic result as shows in table (3). From our results, we confirmed that, the genotypic techniques are very rapid, accurate, more sensitive and reliable compared with phenotypic identification methods $[\mathbf{1 2}, \mathbf{3 4}]$.

\section{Acidifying Ability}

The acidifying ability of the tested strain expressed as $\mathrm{pH}$ decrease in skim milk medium shows in figure (4). The results showed that, the $\mathrm{pH}$ values of skim milk medium was gradually decrease in the first 8 hours of incubation at $37^{\circ} \mathrm{C}$. by extending the incubation time a complete coagulum of the milk medium was observed after $16 \mathrm{~h}$. Our findings are in agreement with obtained results of $[35,36$, 37]

\section{Antibiotic Sensitivity}

As presents in table (4) and figure (5) the tested strain showed high susceptibility and a wide range of resistance to 9 of antibiotic discs Penicillin G, Erythromycin, Ampicillin, Cephalocin, Clindamycin, Cortimoxazole and Nitrofurantion, Whereas the tested strain showed high resistance toward the other antibiotic discs [38].

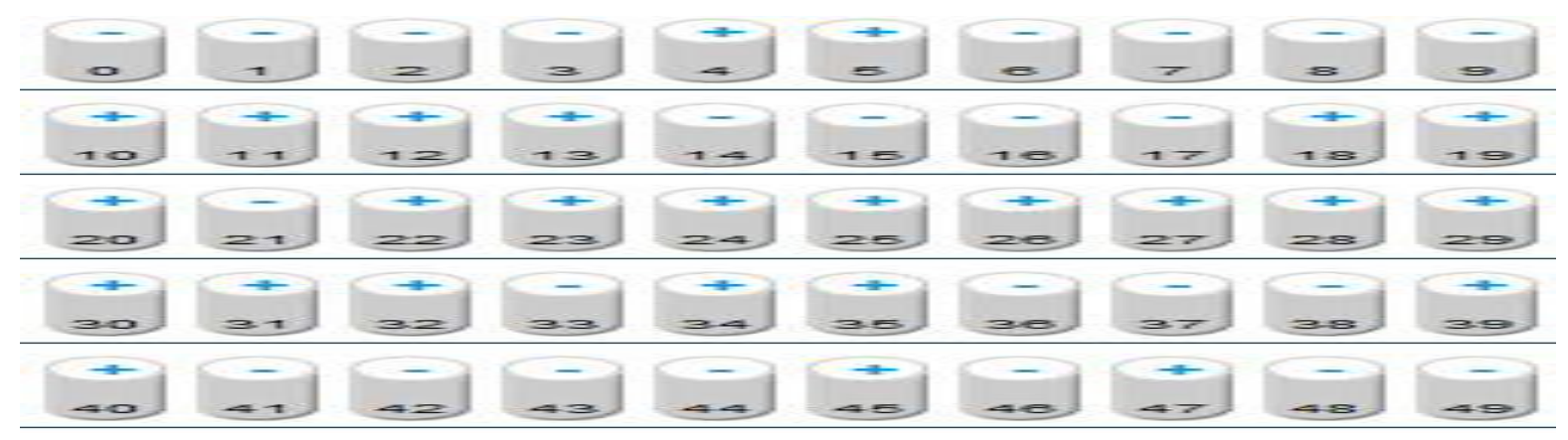

Figure 1: Carbohydrate fermentation profile

0= Control 1= Glycerol 2- Erythritol 3- D-Arabinose 4- L- Arabinose 5= Ribose 6= D-Xylose 7= L-Xylose 8= Adonitol 9= Â Methyl-D-Xyloside 10= Galactose 11= Glucose 12= Fructose 13= Mannose 14= Sorbose 15= Rhamnose 16= Dulcitol 17= Inositol 18= Mannitol 19=Sorbitol 20= á-Methyl-DMannoside 21 = á-Methyl-D-Glucoside 22 = N-Acetyl-Glucosamine 23= Amygdalin 24= Arbutin 25= Esculin 26=Salicin 27=Cellobiose 28= Maltose 29= Lactose 30= Mellibiose 31 $=$ Sucrose 32 $=$ Trehalose 33 $=$ Inulin 34 $=$ Melezitose 35 $=$ Raffinose 36 $=$ Starch 37 $=$ Glycogen 38 $=$ Xylitol 39= Gentiobiose 40= D-Turanose 41= D-Lyxose 42 $=$ D-Tagatose 43 $=$ D-Fucose 44 $=$ L-Fucose 45= D-Arabitol 46= L- Arabitol 47= Gluconate 48=2-Keto-Gluconate 49= 5Keto-Gluconate.

Table 2: Identification result of analytical profile index

\begin{tabular}{|c|c|c|c|}
\hline Strip & \multicolumn{3}{|l|}{ API 50 CHL V5.1 } \\
\hline Profile & \multicolumn{3}{|c|}{ 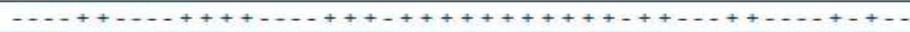 } \\
\hline \multicolumn{4}{|l|}{ Note } \\
\hline \multicolumn{2}{|l|}{ Significant taxa } & $T$ & Tests against \\
\hline Lactobacillus plantarum 1 & 99.9 & 0.98 & \\
\hline
\end{tabular}

Table 3: Similarity of genotypic and phenotypic identification

\begin{tabular}{|c|c|c|c|}
\hline Isolate & identification & Strain & $\%$ \\
\hline \multirow{3}{*}{ NRC AM10 } & Genotypic & Lactobacillus plantarum & 100 \\
\cline { 2 - 4 } & Phenotypic & Lactobacillus plantarum & 99.9 \\
\hline
\end{tabular}




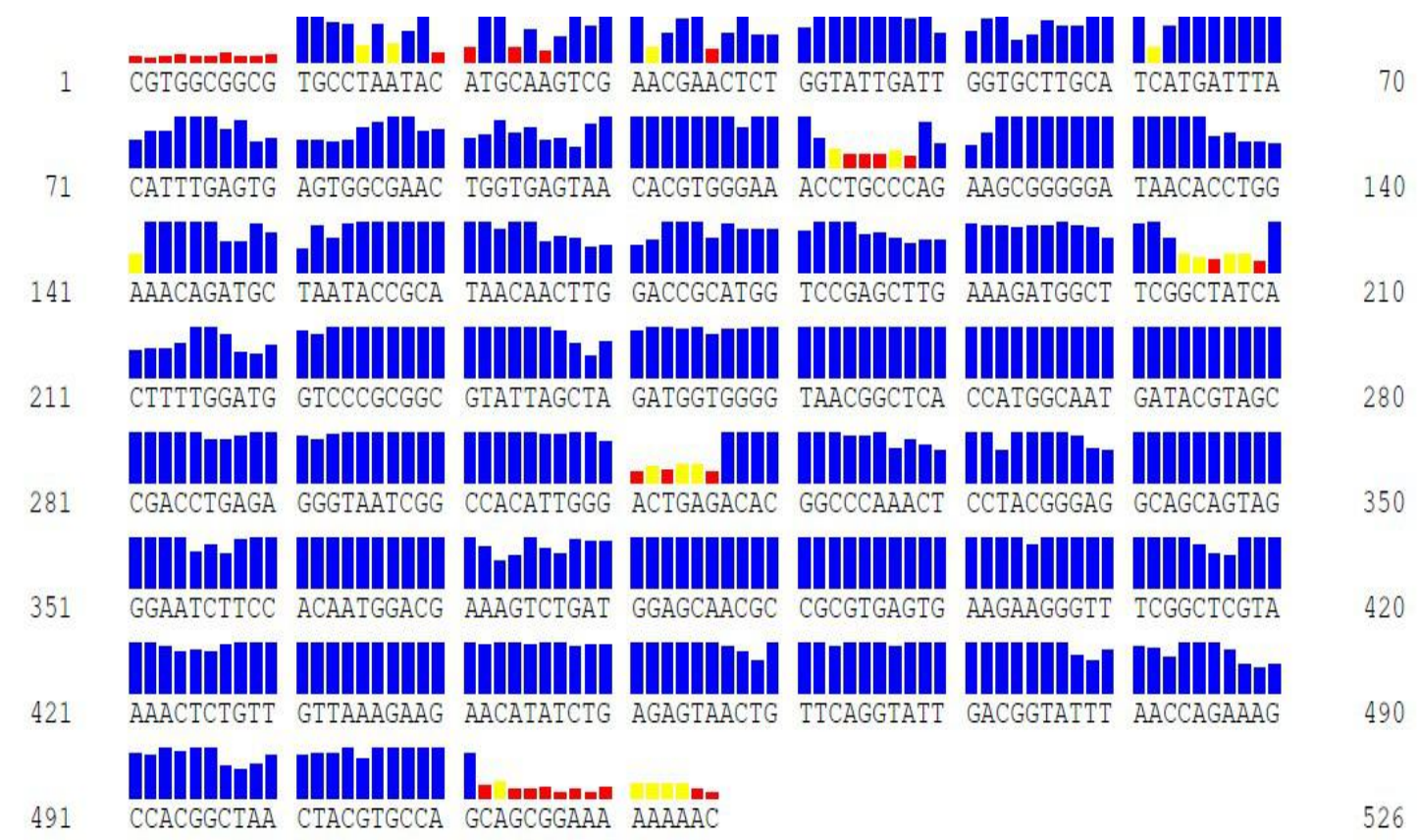

Figure 2: The complete genome sequence of Lactobacillus plantarum AM10

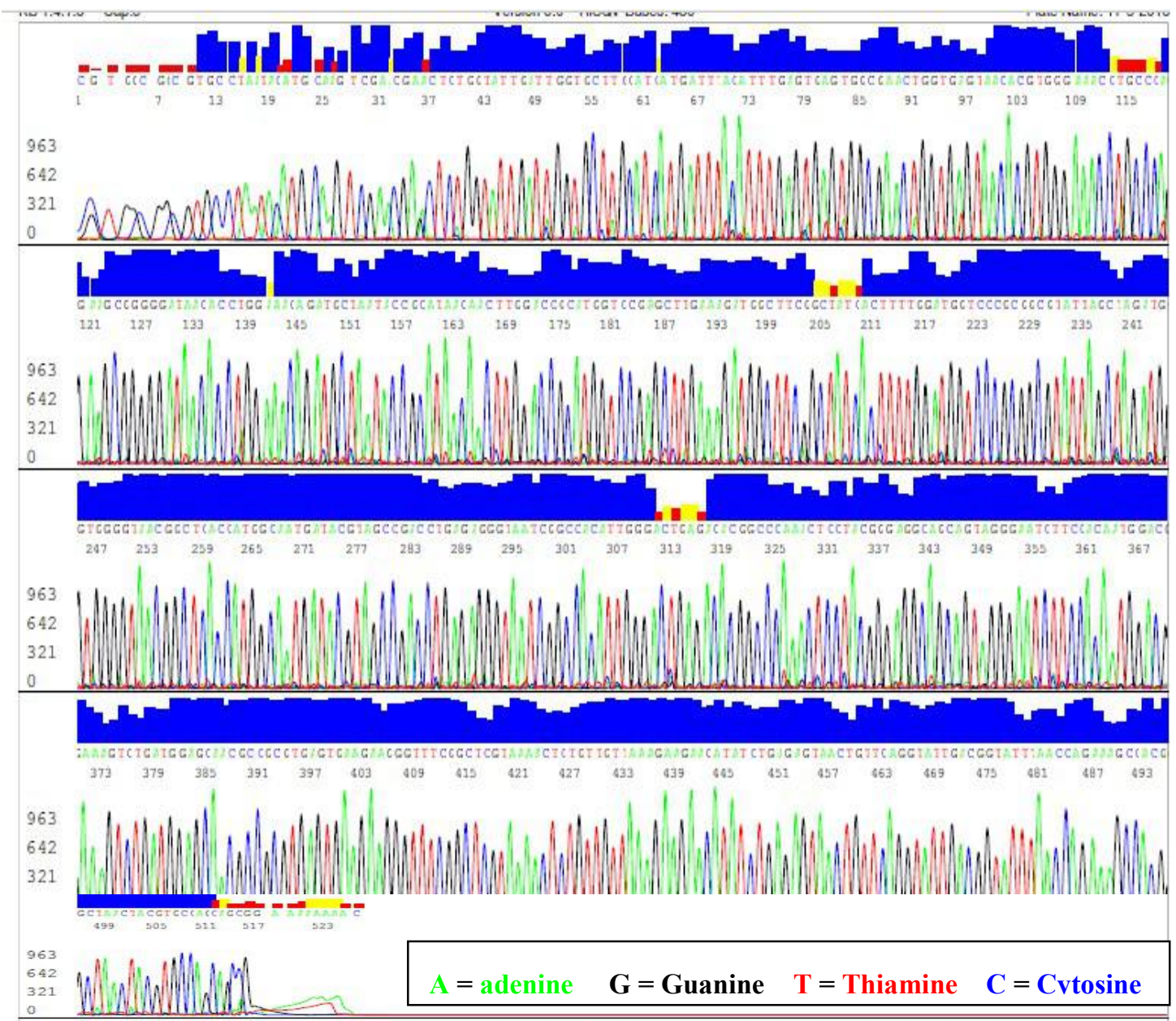

Figure 3: The electropherogram of genome sequence of Lactobacillus plantarum AM10 


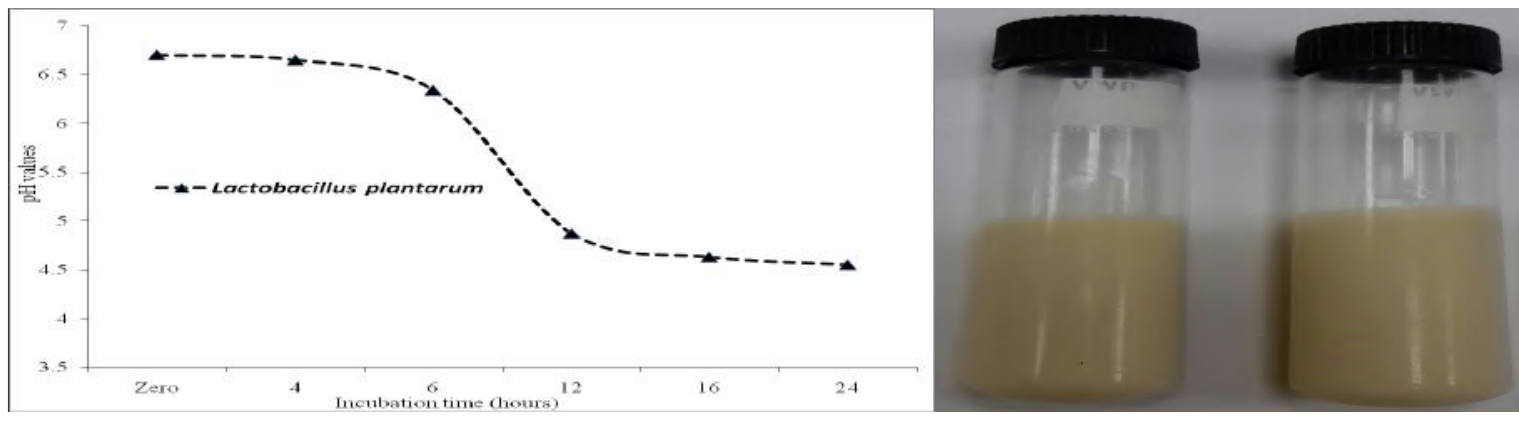

Figure 4: Coagulated sterilized skim milk because of acidity development

Table 4: Antibiotic resistance and sensitivity of Lactobacillus plantarum

\begin{tabular}{|c|c|c|c|c|c|c|c|c|c|c|}
\hline Antibiotic & $\begin{array}{c}\text { PG 10 } \\
\text { units }\end{array}$ & $\begin{array}{c}\text { E } 15 \\
\mu \mathrm{g}\end{array}$ & $\begin{array}{c}\text { Ap } 10 \\
\mu \mathrm{g}\end{array}$ & $\begin{array}{c}\text { KF 10 } \\
\mu \mathrm{g}\end{array}$ & CD $2 \mu \mathrm{g}$ & TS $25 \mu \mathrm{g}$ & $\underset{25 \mu \mathrm{g}}{\mathrm{Ap}}$ & $\begin{array}{c}\text { KF 30 } \\
\mu \mathrm{g}\end{array}$ & $\begin{array}{c}\text { TS 10 } \\
\mu \mathrm{g}\end{array}$ & $\begin{array}{c}\text { NA 30 } \\
\mu \mathrm{g}\end{array}$ \\
\hline Result & $\mathbf{S}$ & $\mathbf{S}$ & $\mathbf{S}$ & $\mathbf{S}$ & $\mathbf{S}$ & $\mathbf{S}$ & $\mathbf{S}$ & $\mathbf{S}$ & $\mathbf{R}$ & $\mathbf{R}$ \\
\hline Antibiotic & $\begin{array}{c}\text { NI } 30 \\
\mu \mathrm{g}\end{array}$ & $\begin{array}{l}\text { NOR } \\
10 \mu \mathrm{g}\end{array}$ & $\begin{array}{c}\text { AK } \\
\mathbf{3 0 \mu \mathrm { g }} \\
\end{array}$ & $\begin{array}{c}\text { PY10 } \\
\mu \mathrm{g}\end{array}$ & $\begin{array}{c}\text { CAZ 30 } \\
\mu \mathrm{g}\end{array}$ & $\begin{array}{c}\text { CRO } 30 \\
\mu \mathrm{g}\end{array}$ & $\begin{array}{c}\text { GM } \\
10 \mu \mathrm{g}\end{array}$ & $\begin{array}{l}\text { NET } \\
30 \mu \mathrm{g} \\
\end{array}$ & $\begin{array}{c}\text { PRL } \\
100 \mu g\end{array}$ & $\begin{array}{c}\text { TN } 10 \\
\mu \mathrm{g}\end{array}$ \\
\hline Result & S & $\mathbf{R}$ & $\mathbf{R}$ & $\mathbf{R}$ & $\mathbf{R}$ & $\mathbf{R}$ & $\mathbf{R}$ & $\mathbf{R}$ & $\mathbf{R}$ & $\mathbf{R}$ \\
\hline
\end{tabular}

$\mathbf{P G}=$ Penicillin G, E= Erythromycin, AP= Ampicillin, KF= Cephalocin, $\mathbf{C D}=\mathbf{C l i n d a m y c i n}, \mathrm{TS}=$ Cortimoxazole, $\mathbf{N A}=$ Nalidixic acid, $\mathrm{NI}=$ Nitrofurantion, $\mathrm{NOR}=$ Norfloxacin, $\mathrm{AK}=$ Amikacin, $\mathrm{PY}=$ Carbenicillin, $\mathrm{CAZ}=$ Ceftazidine, $\mathrm{CRO}=$ Ceftriaxone, $\mathbf{G M}=$ Gentamycin, $\mathbf{N E T}=$ Netilmicin, $\mathbf{P R L}=$ Piperacillin, $T N=$ Tobramycin, $R=$ Resistance and $S=$ Sensitive.

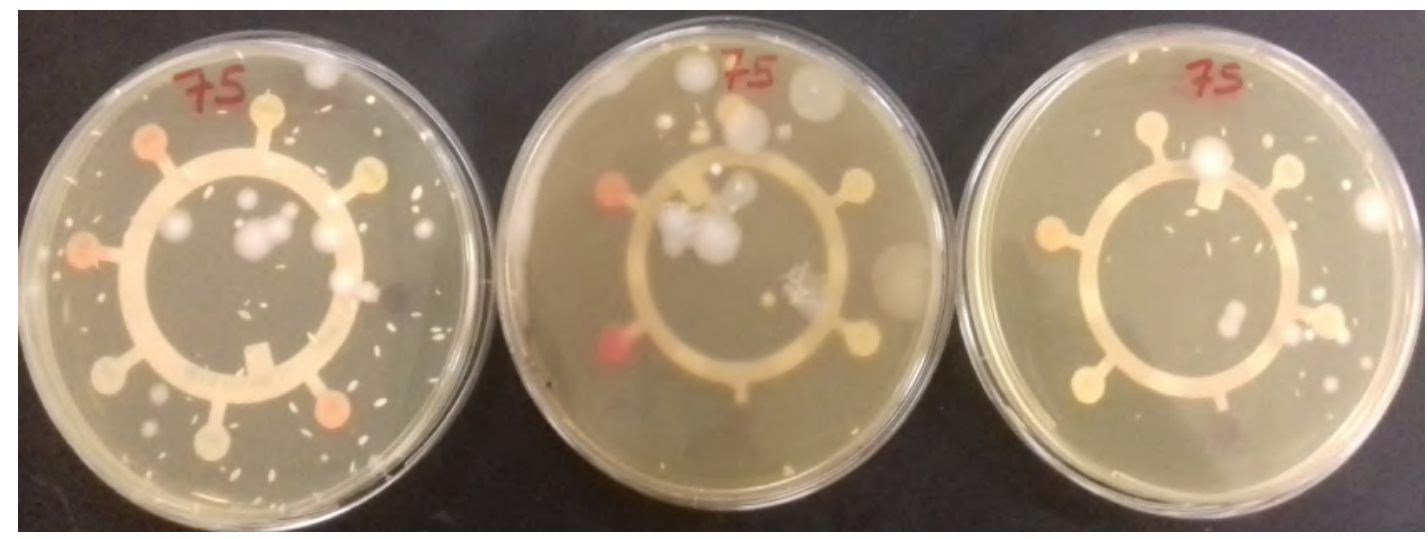

\section{REFERENCES}

[1] Mahasneh, A. M.M., and Abbas, M. M., Probiotics and Traditional Fermented Foods: The Eternal Connection (Mini-Review). Jordan J. of Biological Sci. 3 (4), 2010, 133-140.

[2] Mabrouk, A. M.M, Effat, B.A.M, Sadek, Z. I. M., Tawfik N.F., Hassan, Z.M.R., and Magdoub,
M.N.I., Antibacterial activity of some lactic acid bacteria isolated from Egyptian dairy products. Inter. J. of Chem Tech Research. 6 (2), 2014, $1139-1150$.

[3] Isa, J.K., and Razavi, S.H., Characterization of Lactobacillus plantarum as a Potential Probiotic In vitro and Use of a Dairy Product (Yogurt) as Food Carrier. Applied 
Food Biotechnology. 4 (1), 2017, 11-18.

[4] Abdelazez, A., Abdelmotaal, H., Zhu, Z., Fang-Fang, J., Sami, R., Zhang, L., Al-Tawaha, A., and Meng, X., Potential benefits of Lactobacillus plantarum as probiotic and its advantages in human health and industrial applications: A review. Advances in Environmental Biology 12(1), 2018, 16-27.

[5] Melgar-Lalanne, G., RiveraEspinoza, Y., Farrera-Rebollo, R., and Hernández-Sánchez, H., Survival under stress of halotolerant lactobacilli with probiotic properties. Revista Mexicana de Ingeniería Química. 13, 2014 323335.

[6] Magdoub, M.N.I., Hassan, Z.M.R., Effat, B.A.M., Sadek, Z.I.M., Tawfik, N.F., and Mabrouk, A.M.M., Probiotic properties of some lactic acid bacteria isolated from Egyptian dairy products. Int. J. Curr. Microbiol. App. Sci., 4 (12), 2015, 758-766.

[7] Behera, S. S., Ray,R. C., and Zdolec, N., Review Article Lactobacillus plantarum with Functional Properties: An Approach to Increase Safety and Shelf Life of Fermented
Foods. BioMed Research International, 2018, Article ID 9361614, 18 pages.

[8] FAO/WHO, Guidelines for the evaluation of probiotics in food. Report of a Joint FAO/WHO Working Group on Drafting Guidelines for the Evaluation of Probiotics in Food, Ontario, Canada 2002.

[9] Abou-Donia, S.A., Research on lactic acid in Egypt: An overview. Egypt. J. Dairy Sci., 37, 2009, 1-14.

[10] El-Ghaish, S., Dalgalarrondo, M., Choiset, Y., Sitohy, M., Ivanova, I., Haertle, T., and Chobert, J., Screening of strains of lactococci isolated from Egyptian dairy products for their proteolytic activity. Food Chemistry, 120, 2010, 758-764.

[11] Brolazo, E.M, Leite, D.S,, Tiba, M.R., Villarroel, M., Marconi, C., and Simoes, J.A., Correlation between API $50 \mathrm{CH}$ and multiplex polymerase chain reaction for the identification of vaginal Lactobacilli in isolates. Brazilian journal of microbiology. 42, 2011, 225-232.

[12] Hassan, Z.M.R., Effat, B.A.M., Magdoub, M.N.I., Sadek, Z.I.M., Tawfik, N.F., and Mabrouk, 
A.M.M., Molecular Identification of Lactic Acid Bacteria Isolated From Fermented Dairy Product. International journal of biology, pharmacy and allied sciences. 5 (12), 2016, 3221-3230.

Maragkoudakis, P.A., Zoumpopoulou, G., Miaris, C., Kalantzopoulos, G., Pot, B., and Tsakalidou, E., Probiotic Potential of Lactobacillus Strains Isolated from Dairy Products. Int. Dairy Journal. 16(3), 2006, 189-199.

[14] Cammarota, M., De Rosa, M., Stellavato, A., Lamberti, M., Mazaioli, I., and Giuliano, M., In vitro evaluation of Lactobacillus plantarum DSMZ 12028 as a probiotic: Emphasis on innate immunity. Int. J Food Microbiol. 135, 2009, 90-98.

[15] Abd El-Gawad, I.A., Abd El Fatah, A.M., and Al Rubbayyi, K.A., Identification and characterization of dominant lactic acid bacteria isolated from traditional Rayeb milk in Egypt. J. of Am. Sci. 6 (10), 2010,728 -735.

[16] Barbosa, M.S., Todorov, S.D., Ivanova, I.V., Belguesmia, Y., Choiset, Y., Rabesona, H., Chobert, J.M., Haertl, T., and Franco, B.D.G.M.,
Characterization of a two-peptide plantaricin produced by Lactobacillus plantarum MBSa4 isolated from Brazilian salami. Food Control. 60, 2016, 103-112.

[17]

Fernandes, P., Loureiro, D., Monteiro， V., Ramos， C., Nero, L. A., Todorov, S.D., and Guerreiro, J.S., Lactobacillus plantarum isolated from cheese: production and partial characterization of bacteriocin B391. Annals of Microbiol. 67 (6), $2017,433-442$.

[18] Katz, J., Probiotics for prevention of antibiotic-associated diarrhea and clostridium difficile diarrhea. J. Clin. Gastroenterol. 40, 2006, 249 255.

[19] Snydman, D.R., The safety of probiotics. Clin Infect Dis. 46 (2), 2008, S104-S 111.

[20] Hummel, A.S., Hertel, C., Holzapfel, W.H., and Franz, C.M., Antibiotic resistances of starter and probiotic strains of lactic acid bacteria. Appl. Environ. Microbiol. 73, 2007, 730739.

[21] Mayrhofer, S., Van Hoek, A.H., Mair, C., Huys, G., Aarts, H.J., Kneifel, W., and Domig, K.J., Antibiotic susceptibility of members of the Lactobacillus 
acidophilus group using broth microdilution and molecular identification of their resistance determinants. Int. J. Food Microbiol. 15 (144), 2010, 81- 87.

[22] Lin, C.F., Fung, Z.F., Wu, C.L., and Chung, T.C., Molecular characterization of a plasmid-borne (pTC82) chloramphenicol resistance determinant (cat-TC) from Lactobacillus reuteri G4. Plasmid. 36, 1996, 116-124.

[23] Ahn, C., Collins-Thompson. D., Duncan, D., and Stiles. M.E., Mobilization and location of the genetic determinant of chloramphenicol resistance from Lactobacillus plantarum caTC2R. Plasmid. 27, 1992, 169-176.

[24] Gueimonde, M., Sánchez, B., De los Reyes-Gavilán, C.G., and Margolles, A., Antibiotic resistance in probiotic bacteria. Frontiers in Microbiol. (4) 202, 2013,1-6.

[25] Christy, A., Varughese, Vakil, N.H., and Phillips, K.M., Antibiotic Associated Diarrhea A Refresher on Causes and Possible Prevention With Probiotics. Journal of Pharmacy Practice 26 (5), 2013, 476-482.

[26] Hempel, S., Newberry, S.J., Maher, A.R., Wang, Z., Miles, J.N.V.,
Shanman, B., Johnsen, R., and Shekelle, P.G., Probiotics for the Prevention and Treatment of Antibiotic-Associated Diarrhea A. Systematic Review and Metaanalysis Journal American Medical Association. 307 (18), 2012, 19591969.

[27] Goldenberg, J.Z., Lytvyn, L., Steurich, J., Parkin, P., Mahant, S., and Johnston, B.C., Probiotics for the prevention of pediatric antibiotic-associated diarrhea. Cochrane Database Syst. Rev. 12, 2015, CD004827. doi: $10.1002 / 14651858$.

[28] Szajewska, H., Canani, R.B., Guarino, A., Hojsak, I., Indrio, F., Kolacek, S., Orel, R., Shamir, R., Vandenplas, Y., Van Goudoever, J.B., and Weizman, Z., Probiotics for the Prevention of AntibioticAssociated Diarrhea in Children. Journal of Pediatric Gastroenterology and Nutrition. 62 (3), 2016, 495-506.

[29] Bergey, D.H., Harrison, F.C., Breed, R.S., Hammer, B.W., and Huntoon, F.M., Bergey's Manual of Determinative Bacteriology. 1989, $9^{\text {th }}$ Ed. The William and Wilkins Company. London. 
[30] Sanger, F.S.N., and Coulson, A.R., DNA sequencing with chainterminating inhibitors. Proc. Natl. Acad. Sci. USA, 74, 1977, 54635467.

[31] El-Soda, M., El-Zeiney, M., Awad, S., Osman, G., Omarn, N., Gamal, G., Ezzat, N., and El Shafei, H., A culture collection of lactic acid bacteria isolated from raw milk and traditional Egyptian dairy products. Egypt. J. Dairy Sci. 31, 2003, 2341.

[32] Georgieva, R., Iliev, I., Haertle, T., Chobert, J., Ivanova, I., and Danova, S., Technological properties of candidate probiotic Lactobacillus plantarum strains. Int. Dairy Journal 19, 2009, 696-702.

[33] Charteris, W.P., Kelly, P.M., Morelli, L., and Collins, J.K., Antibiotic susceptibility of potentially probiotic Lactobacillus species. J. Food Prot. 61, 1998,1636-1643.

[34] Moraes, P.M., Perin, L.M., Junior, A.S., and Nero, L.A., Comparison of phenotypic and molecular tests to identify lactic acid bacteria. Brazilian J. of Microbiol. 44 (1), 2013, 109-112.

[35] Ayad, E.H.E., Nashat, S., El-Sedek, N., Metwally, H, and El-Soda, M.,
Selection of wild lactic acid bacteria isolated from traditional Egyptian dairy products according to production and technological criteria. Food Microbiol. 21, 2004, $15-725$.

[36] Malek, R., El-Attar, A., Mohamed, M., Anwar, S., El-Soda, M., and Béal, C., Technological and safety properties display biodiversity among enterococci isolated from two Egyptian cheeses, "Ras" and "Domiati". Int. J. of Food Microbiol. 153, 2012, 314-322.

[37] Ibrahim, M.K., Effat, B.A.M., Tawfik, N.F., Mehanna, N.S., and Soliman, N.R., Evaluation of probiotic potential of dairy propionibacteria. Journal of Innovations in Pharmaceutical and Biological Sciences 4 (3), 2017, 3442.

[38] Ammor, S., Tauveron, G., Dufour, E., and Chevallier, I., Antibacterial activity of Lactic acid bacteria against spoilage and pathogenic bacteria isolated from the same meat small-scale facility. 1. Screening and characterization of the antibacterial compounds. Food Control., 17, 2007, 454-461. 